\title{
Direct and Lagged Effects of Spring Phenology on Net Primary Productivity in the Alpine Grasslands on the Tibetan Plateau
}

\author{
Zhoutao Zheng ${ }^{1}\left(\mathbb{D}\right.$, Wenquan Zhu ${ }^{2}$ and Yangjian Zhang ${ }^{1,3,4, *}$ \\ 1 Key Laboratory of Ecosystem Network Observation and Modeling, Institute of Geographic Sciences and \\ Natural Resources Research, Chinese Academy of Sciences, Beijing 100101, China; zhengzt@igsnrr.ac.cn \\ 2 Faculty of Geographical Science, Beijing Normal University, Beijing 100875, China; zhuwq75@bnu.edu.cn \\ 3 CAS Center for Excellence in Tibetan Plateau Earth Sciences, Chinese Academy of Sciences, Beijing 100101, \\ China \\ 4 College of Resources and Environment, University of Chinese Academy of Sciences, Beijing 100190, China \\ * Correspondence: zhangyj@igsnrr.ac.cn; Tel.: +86-010-6488-9703
}

Received: 4 March 2020; Accepted: 9 April 2020; Published: 10 April 2020

\begin{abstract}
As a key biotic factor, phenology exerts fundamental influences on ecosystem carbon sequestration. However, whether spring phenology affects the subsequent seasonal ecosystem productivity and the underlying resource limitation mechanism remains unclear for the alpine grasslands of the Tibetan Plateau (TP). In this study, we investigated the direct and lagged seasonal responses of net primary productivity (NPP) to the beginning of growing season (BGS) along a precipitation gradient by integrating field observations, remote sensing monitoring and ecosystem model simulations. The results revealed distinct response patterns of seasonal NPP to BGS. Specifically, the BGS showed a significant and negative correlation with spring NPP $(R=-0.73, p<0.01)$, as evidenced by the direct boosting effects of earlier BGS on spring NPP. Moreover, spring NPP was more responsive to BGS in areas with more annual precipitation. The boosting effects of earlier BGS on NPP tended to weaken in summer compared with that in spring. Sequentially, BGS exhibited stronger positive correlation with autumn NPP in areas with less annual precipitation, which suggested the enhanced lagged suppressing effects of earlier spring phenology on ecosystem carbon assimilation during the later growing season under aggravated water stress. Overall, the strengthened NPP in spring was offset by its decrement in autumn, resulting in no obvious relationship between BGS and annual NPP $(R=-0.34, p>0.05)$ for the entire grasslands on the TP. The findings of this study imply that the lagged effects of phenology on the ecosystem productivity during the subsequent seasons should not be neglected in the future studies.
\end{abstract}

Keywords: spring phenology; net primary productivity; lagged effect; alpine grasslands; precipitation; Tibetan Plateau

\section{Introduction}

Climate change affects ecosystem carbon balance directly through changing photosynthesis, and indirectly through adjusting biological processes [1]. Under certain circumstances, the indirect effects might contribute to a higher proportion of variation than the direct effects do [2,3]. As one of the key biogeochemical processes influenced by climate, phenology exerts tight controls on ecosystem carbon sequestration and productivity $[4,5]$. During recent decades, satellite and ground-based evidences show that phenology has experienced significant shifts in response to climate change [6-9], which unavoidably influences exchanges of carbon, water and energy between vegetation and the atmosphere [10,11]. 
As the 'third pole' of the planet, the Tibetan Plateau (TP) is the highest plateau in the world. It covers an area of approximately 2.5 million $\mathrm{km}^{2}$ and has an average altitude higher than $4000 \mathrm{~m}$ [12]. The alpine grassland (mainly composed of alpine meadow and steppe) is the dominant vegetation type on the TP, which is extremely sensitive to climate change [13]. As a major constituent of the carbon pool in the alpine ecosystem, alpine grasslands play a crucial role in regulating the regional carbon balance [14]. In recent decades, the TP has experienced unprecedented climate warming [15], which has affected various aspects of the fragile ecosystems, including shifted phenology and fluctuated ecosystem productivity $[16,17]$. However, how phenology regulates ecosystem productivity is still a bottleneck for us to understand the responses of global carbon cycles to climate change.

In the TP, various land surface phenological metrics (e.g., the start, end and length of the growing season) have been investigated for their effects on ecosystem carbon assimilation [18-21]. However, these studies mainly concerned the relationship between phenological metrics and annual ecosystem productivity. How phenology affects ecosystem productivity of each individual season is still largely obscure for the TP. The lagged effects of spring phenology on ecosystem productivity during the subsequent summer and autumn in particular have not been adequately investigated. Earlier spring growth may cause mixed effects on the subsequent ecosystem productivity of each individual season in different environments [5,22]. Previous studies reported that warming-induced earlier onset of the growing season would result in a longer growing season in some forest ecosystems, which in turn leads to strengthened ecosystem productivity [23,24]. However, earlier spring phenology might inhibit carbon assimilation, due to aggravated water stress in summer or autumn for the water-limited grassland ecosystems $[25,26]$. Water availability is one of the critical environment factors that regulate the response of vegetation productivity to spring phenology. Previous studies had revealed earlier spring phenology could aggravate soil moisture deficits in later growth stages by increasing evapotranspiration $[27,28]$, leading to suppressed vegetation activities. However, few studies have reported the linkage between water resource limitation and the lagged effects of spring phenology on the ecosystem productivity in the subsequent seasons on the TP. The TP is characterized with frigid and dry environments [13]. Spatially, the annual precipitation in this region decreases from southeast to northwest [29]. Under climate warming, start of growing season has advanced significantly in the past decades in the TP [16,17]. The combination of arid environments and earlier spring phenology provides a unique opportunity for investigating the direct and lagged effects of spring phenology on ecosystem productivity.

In this study, our objectives were to investigate how spring phenology and climatic variables co-regulate carbon assimilation in direct and lagged ways for the alpine grasslands of the TP during 2001-2015, based on remote sensing data. Utilizing regionally optimized ecosystem productivity model and in-situ validated land surface phenology, our specific objectives were (1) to identify how spring phenology influences seasonal net primary productivity (NPP) during spring and the subsequent summer and autumn, and (2) to reveal the water resource limitation mechanism underlying the linkage between spring phenology and ecosystem productivity by direct and lagged effects.

\section{Materials and Methods}

\subsection{Datasets}

The Normalized Difference Vegetation Index (NDVI) is commonly used for land surface phenology and ecosystem productivity estimation. In this study, we used the 16-day composite NDVI product (MOD13Q1, Collection 6, downloaded from: https://ladsweb.modaps.eosdis.nasa.gov) covering 2001-2015 at $250 \mathrm{~m}$ spatial resolution from the Moderate Resolution Imaging Spectroradiometer (MODIS) Terra satellite. Noises caused by cloud and snow contamination were further removed [29]. A time series of annual minimum and uncontaminated NDVI was generated for each pixel during 2001-2015. The median value in the minimum NDVI time series was then extracted as the background NDVI value, which was later used to replace the smaller values and snow flagged values [30]. Moreover, 
we removed the remaining cloud contamination in NDVI time series by using Savitzky-Golay filter [31]. The 16-day temporal resolution NDVI was used to extract beginning of growing season (BGS). In addition, the maximum value composite (MVC) method was used to construct the monthly NDVI data for the calculation of monthly NPP [32]. To avoid the uncertainty caused by land cover change, we only considered pixels where grassland cover type remained identical during 2001-2015, according to the criteria set in a previous study [33]: (1) the average NDVI for June-September should be greater than 0.1 ; (2) the annual maximum NDVI should exceed 0.15 and occur within July-September; (3) the average NDVI for July-September should be greater than 1.2 times the average NDVI for November-March; and, (4) the average NDVI in winter (December-February) should be lower than 0.4. In addition, the green-up (also termed as MCD12Q2-derived BGS) derived from the MODIS Land Cover Dynamics Collection 6 dataset (MCD12Q2) (https://pdaac.usgs.gov/products/mcd12q2v006/) was compared in performance with BGS derived from MOD13Q1 NDVI in this study.

Field data during 2001-2012 collected by China Meteorological Administration (CMA) were used to validate satellite-derived BGS and model-simulated NPP (Figure 1) [17]. The field sites are composed of eight phenology observations and seven biomass observations, and they cover both alpine meadow and steppe. Phenology and biomass observations were carried out in fenced natural pastures with an area of $100 \mathrm{~m} \times 100 \mathrm{~m}$ at each station. The species-specific phenology was observed every two days, in accordance with uniform observation criteria [34]. The green-up date is identified when $10 \%$ of individual grasses per species at each station display leaves and grow up to $1 \mathrm{~cm}$ in spring. The monitored species is listed in Table 1. The multispecies mean green-up date in each year at each station was derived to represent the phenological status of the local plant community [35]. According to the observation criteria [34], four random plots $(1 \mathrm{~m} \times 1 \mathrm{~m})$ were selected to measure aboveground dry biomass in each month during the growth period. For grasslands, NPP can be estimated by peak biomass [36]. The belowground biomass was estimated according to the average ratio of belowground to aboveground net production (3.18) for alpine grasslands [29]. The total biomass $\left[\mathrm{g} \mathrm{m}^{-2}\right]$ was converted to NPP $\left[\mathrm{g} \mathrm{C} \mathrm{m}^{-2}\right]$ with a factor of 0.45 [37].

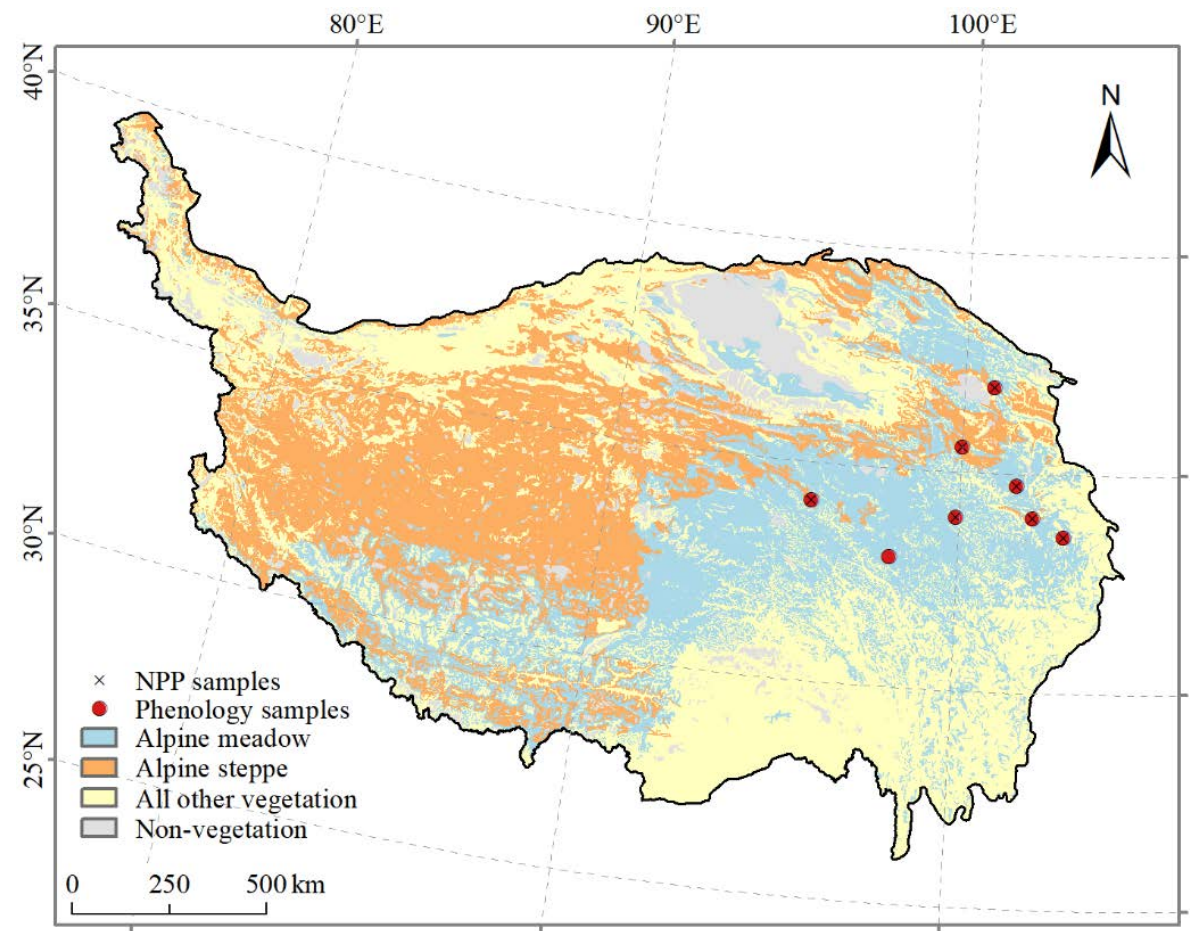

Figure 1. Spatial distribution of the biomes, net primary productivity (NPP) and grassland phenology sampling sites on the Tibetan Plateau. 
Table 1. Geographical coordinates, elevation, and observed species at each station.

\begin{tabular}{|c|c|c|c|c|}
\hline Site & Longitude (E) & Latitude (N) & Elevation (m) & Species \\
\hline Maqu & $102^{\circ} 05^{\prime}$ & $34^{\circ} 00^{\prime}$ & 3471 & $\begin{array}{l}\text { Elymus nutans, Poa botryoides, } \\
\text { Taraxacum mongolicum }\end{array}$ \\
\hline Haiyan & $100^{\circ} 51^{\prime}$ & $36^{\circ} 57^{\prime}$ & 3140 & $\begin{array}{l}\text { Kobresia humilis, Plantago } \\
\text { asiatica, Koeleria cristata, Poa } \\
\text { crymophila, Iris lacteal Pall. var. } \\
\text { chinensis, Taraxacum } \\
\text { mongolicum, Stipa krylovii, } \\
\text { Artemisia scoparia }\end{array}$ \\
\hline Xinghai & $99^{\circ} 59^{\prime}$ & $35^{\circ} 35^{\prime}$ & 3323 & $\begin{array}{l}\text { Agropyron cristatum, Plantago } \\
\text { asiatica, Aneurolepidium } \\
\text { dasystachys, Iris lacteal Pall. var. } \\
\text { chinensis, Taraxacum } \\
\text { mongolicum, Stipa krylovii }\end{array}$ \\
\hline Qumarleb & $95^{\circ} 47^{\prime}$ & $34^{\circ} 08^{\prime}$ & 4175 & $\begin{array}{l}\text { Plantago asiatica, Kobresia } \\
\text { pygmaea, Poa alpina, Taraxacum } \\
\text { mongolicum, Carex montana, } \\
\text { Festuca ovina }\end{array}$ \\
\hline Gande & $99^{\circ} 54^{\prime}$ & $33^{\circ} 58^{\prime}$ & 4050 & $\begin{array}{l}\text { Kobresia humilis, Plantago } \\
\text { asiatica, Elymus nutans, Koeleria } \\
\text { cristata, Gentiana algida, } \\
\text { Taraxacum mongolicum, Festuca } \\
\text { ovina }\end{array}$ \\
\hline Henan & $101^{\circ} 36^{\prime}$ & $34^{\circ} 44^{\prime}$ & 3500 & $\begin{array}{l}\text { Plantago asiatica, Elymus nutans, } \\
\text { Scirpus distigmaticus, Kobresia } \\
\text { pygmaea, Puccinellia tnuifora }\end{array}$ \\
\hline Shiqu & $98^{\circ} 06^{\prime}$ & $32^{\circ} 59^{\prime}$ & 4200 & $\begin{array}{l}\text { Elymus nutans, Taraxacum } \\
\text { mongolicum }\end{array}$ \\
\hline Zoige & $102^{\circ} 58^{\prime}$ & $33^{\circ} 35^{\prime}$ & 3440 & $\begin{array}{l}\text { Poa pratensis, Plantago asiatica, } \\
\text { Koeleria cristata, Taraxacum } \\
\text { mongolicum, Carex montana }\end{array}$ \\
\hline
\end{tabular}

The monthly meteorological data of 172 stations on the TP and surrounding areas during 2001-2015 were collected from the China Meteorological Data Service System (http://data.cma.cn/), including mean temperature, total precipitation, percentage of sunshine and total solar radiation. Since solar radiation data is only available in 26 stations, we used the Angstrom-Prescott model to calculate the monthly total solar radiation for all stations based on the percentage of sunshine [38,39]. Lastly, the meteorological data was interpolated into $250 \mathrm{~m} \times 250 \mathrm{~m}$ raster grids using ANUSPLIN 4.3 software [40]. The digitalized China Vegetation Map with a scale of 1:1000000 was utilized to obtain the distribution of alpine meadow and steppe (Figure 1) [41]. In this study, all data were re-projected to the Albers conic equal area projection.

\subsection{Determination of Land Surface Phenology}

The temporal variations in NDVI during the growth period were fitted by a piecewise logistic function as follow [42]

$$
y(t)=\frac{c}{1+e^{a+b t}}+d
$$

where $t$ is the time (day of year, DOY); $y(t)$ is the NDVI value at time $t ; a$ and $b$ are fitting parameters; $c+d$ is the maximum NDVI value; and $d$ is the initial background NDVI value. The BSG is defined as the date when the curvature change rate reaches the first local maximum value. 


\subsection{Simulation of NPP}

The Carnegie-Ames-Stanford Approach (CASA) model, a light use efficiency model, was adopted to simulate NPP $[43,44]$. In the CASA model, NPP is estimated from the absorbed photosynthetically active radiation $(A P A R)$ and the actual light use efficiency $(\varepsilon)$ as follows:

$$
\begin{gathered}
N P P(x, t)=A P A R(x, t) \times \varepsilon(x, t) \\
\operatorname{APAR}(x, t)=\operatorname{SOL}(x, t) \times \operatorname{FPAR}(x, t) \times 0.5 \\
\varepsilon(x, t)=T_{\varepsilon 1}(x, t) \times T_{\varepsilon 2}(x, t) \times W_{\varepsilon}(x, t) \times \varepsilon_{\text {max }}(x, t)
\end{gathered}
$$

where $x$ is the specific geographic coordinate and $t$ is the time; SOL is the total solar radiation; FPAR is the fraction of photosynthetic active radiation $(P A R)$ absorbed by vegetation canopy and is determined from NDVI; the coefficient of 0.5 is the fraction of active incoming solar radiation (wavelength range of $0.4-0.7 \mu \mathrm{m}$ ) utilized by vegetation; $\varepsilon_{\max }$ refers to the maximum light use efficiency under ideal conditions; $T_{\varepsilon 1}$ and $T_{\varepsilon 2}$ are the temperature stress coefficients representing the restriction of low and high temperature on LUE; and $W_{\varepsilon}$ is the water stress coefficient. More detailed information on the parameters calculation can refer to our previous studies $[29,45]$.

The $\varepsilon_{\max }$ was set to be a constant value of $0.389 \mathrm{~g} \mathrm{C} \mathrm{MJ}^{-1}$ for all vegetation types in the original CASA model [44], but it actually differs with vegetation types [45]. Our prior study had optimized the parameter of $\varepsilon_{\max }$ for the alpine grasslands $\left(0.4812 \mathrm{~g} \mathrm{C} \mathrm{MJ}^{-1}\right)$ using field measurements [29].

\subsection{Statistical Analyses}

To validate satellite-derived phenology and ecosystem productivity using field observations, a $3 \times$ 3 window average encompassing each site was extracted in consideration of the geospatial inaccuracies of the observed sites. The performance of satellite-derived BGS and NPP were assessed by the coefficients of determination $\left(R^{2}\right)$ and $p$-values. The mean error $(\mathrm{ME})$, median absolute error (MAE) and root mean square error (RMSE) were adopted as indicators of model accuracy. The direct and lagged effects of spring phenology on ecosystem productivity were estimated utilizing the Pearson correlations between BGS and NPP during spring and subsequent seasons. The Pearson correlations between BGS and NPP were also generated at a pixel level to analyze the spatial variations in the response of NPP to BGS for spring (March-May), summer (June-August), autumn (September-November) and the entire year, respectively. To evaluate regulation effects of precipitation on the relationships between BGS and seasonal NPP, we also conducted the Pearson correlation analysis between BGS and NPP for different biomes and precipitation intervals on the TP. The annual total precipitation was divided into three classes: 0-400 mm (arid areas), 400-600 mm (semi-arid areas) and >600 mm (dry sub-humid or humid areas) [46]. To identify the predominant direction of the detected significant relationships, the ratios of area with negative correlations to that with positive correlations at both $1 \%$ and $5 \%$ significant levels were used [47]. The threshold values of $>2.0$ (or $<0.5$ ) indicates a strong asymmetry biasing towards significant negative (or positive) correlations [47].

\section{Results}

\subsection{Ground Validation of Satellite-Derived BGS and NPP}

The satellite-derived BGS used in this study displayed close agreement with field observations, as evidenced by ME of 5.8, MAE of 7.0 and RMSE of 9.7 days $\left(R^{2}=0.62, p<0.001\right)$ (Figure 2a). By comparison, the MCD12Q2-derived BGS exhibited a greater bias from field observations, generating ME of 21.3, MAE of 21.0 and RMSE of 23.1 days $\left(R^{2}=0.43, p<0.001\right)$ (Figure $\left.2 \mathrm{~b}\right)$. This comparison indicated BGS, derived from MOD13Q1 with piecewise logistic model, achieved higher accuracies in monitoring grassland spring phenology in the TP. The model-simulated NPP was significantly and positively correlated with field-observed ones, resulting in an $R^{2}$ of $0.79(p<0.001)$ (Figure 3), ME of 
-16.68, MAE of 56.04 and RMSE of $87.59 \mathrm{~g} \mathrm{C} \mathrm{m}^{-2} \mathrm{yr}^{-1}$. The validation indicated that the modified CASA model could effectively capture the spatio-temporal variations in NPP for the alpine grasslands on the TP.
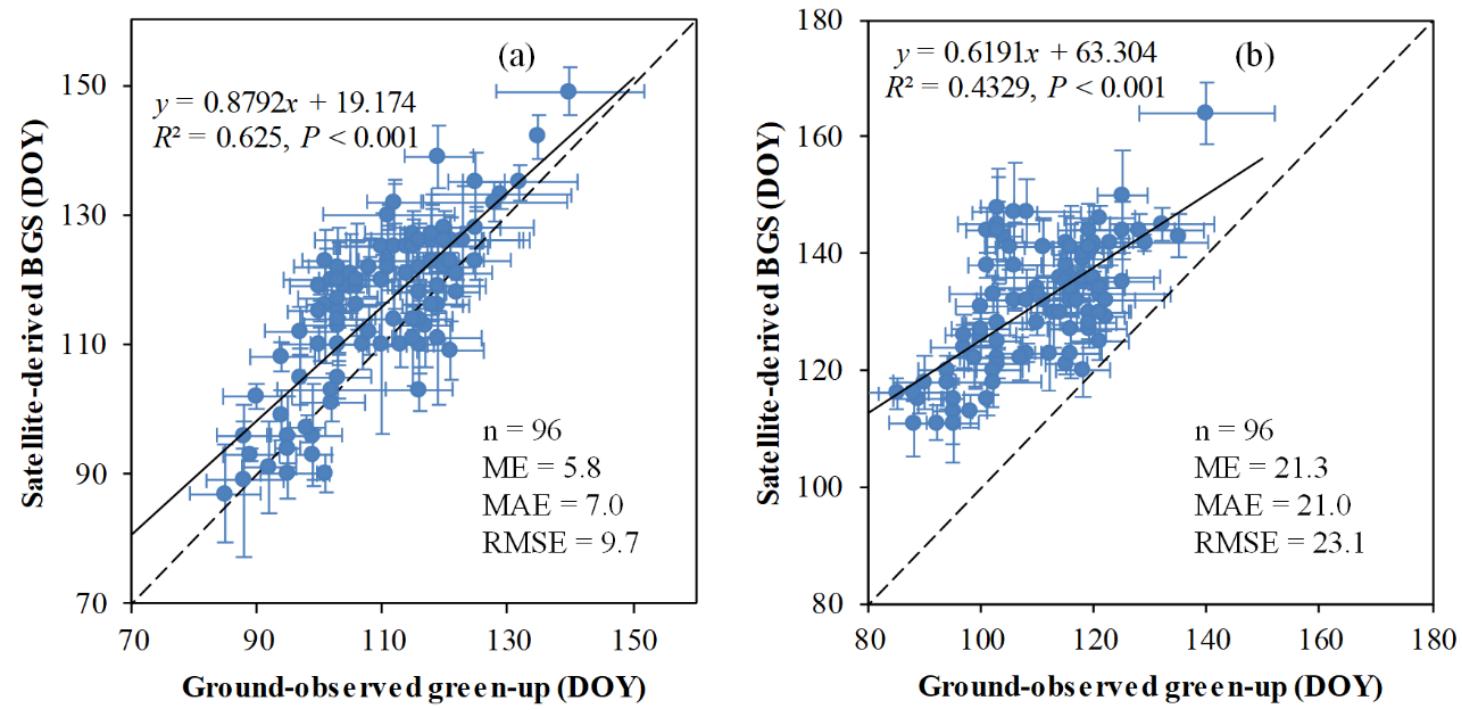

Figure 2. Comparisons of ground-observed multispecies mean green-up date and satellite-derived beginning of growing season (BGS) based on (a) MOD13Q1 and (b) MCD12Q2 product. Points represent data for each site in each year during 2001-2012. Error bar in x-axis indicates the standard deviation of the ground-observed green-up dates across all species at each station. Error bar in y-axis indicates the standard deviation of satellite-derived BGS within $3 \times 3$ window for each station. Solid line represents regression line and dash line represents 1:1 line.

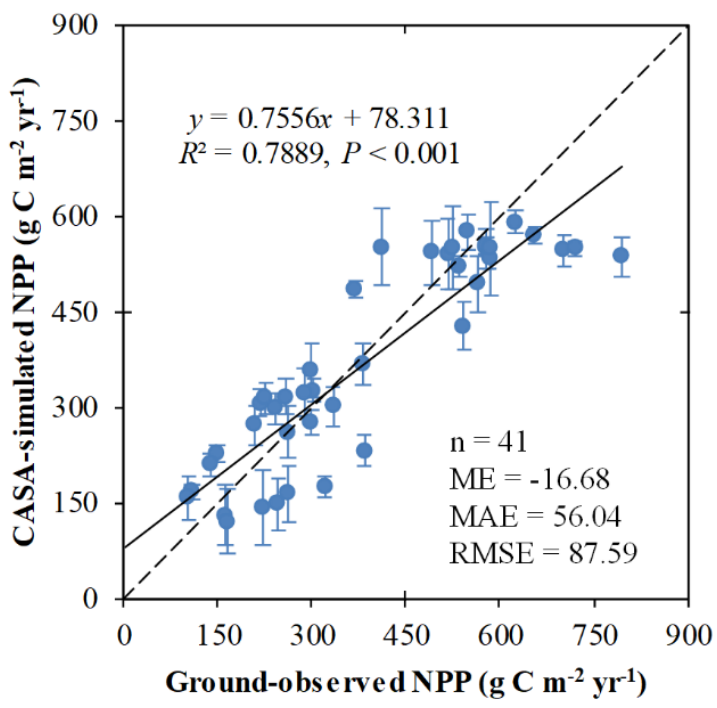

Figure 3. Comparison of ground-observed and Carnegie-Ames-Stanford Approach (CASA)-simulated net primary productivity (NPP). Points represent data for each site in each year during 2001-2012. Error bar in $\mathrm{y}$-axis indicates the standard deviation of CASA-simulated NPP within $3 \times 3$ window for each station. Solid line represents regression line and dash line represents 1:1 line.

\subsection{Spatial Variations in Seasonal Responses of NPP to BGS}

The responses of NPP to BGS exhibited high seasonal variations (Figure 4, Table 2). Spring NPP showed predominant negative correlations with BGS, with $38.74 \%$ of the grasslands being significantly correlated at the $p<0.05$ level and mostly distributed in the central and eastern parts of the TP (Figure 4a). Significant positive correlations $(p<0.05)$ between BGS and spring NPP were only 
observed for $0.57 \%$ of the grasslands. In contrast, summer NPP showed weaker negative responses to BGS but the negative relationship was still predominated (Table 2). Significant negative correlations $(p<0.05)$ accounted for $10.96 \%$ of the grasslands, mostly in the central and southwestern parts of the TP (Figure $4 \mathrm{~b}$ ). Significant positive correlations $(p<0.05)$ between summer NPP and BGS were mostly found in the eastern $\mathrm{TP}$, covering $2.71 \%$ of the grasslands. In autumn, more widespread positive correlations between NPP and BGS were observed compared to spring and summer (Figure 4c). Autumn NPP exhibited predominant positive correlations with BGS (Table 2). Significant positive correlations $(p<0.05)$ were mainly observed in the southwestern part of the TP, covering $8.21 \%$ of the grasslands. Only in $1.27 \%$ of the grasslands were there statistically significant negative correlations $(p<0.05)$ between BGS and autumn NPP. In terms of the entire year, the negative correlation between BGS and annual NPP was found to be statistically significant $(p<0.05)$ in $9.28 \%$ of the grasslands, primary in the central and southwestern TP (Figure $4 \mathrm{~d}$ ). Meanwhile, significant positive correlations $(p<0.05)$ accounted for only $1.74 \%$ of the entire grasslands.
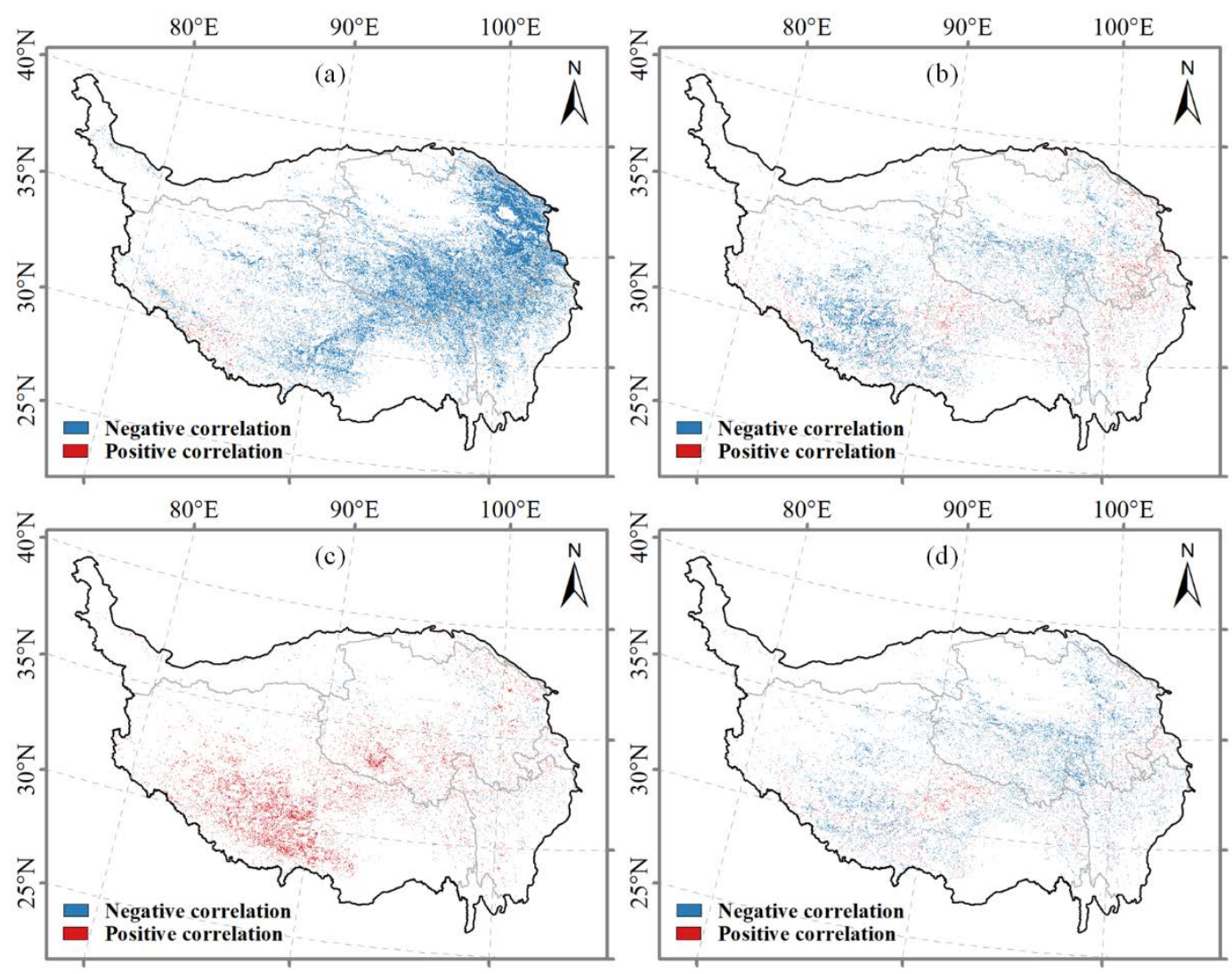

Figure 4. Spatial pattern displaying the correlations between beginning of growing season (BGS) and net primary productivity (NPP) in (a) spring, (b) summer, (c) autumn and (d) the entire year. Only significant correlations $(p<0.05)$ are shown. 
Table 2. Areal percentage of significant correlations between beginning of growing season (BGS) and seasonal or annual net primary productivity (NPP), and the ratio of negative correlated area to positive correlated area in different grassland types. Ratio values in bold and in italics indicate ratio of negative correlated area to positive correlated area $>2.0$ and $<0.5$, respectively.

\begin{tabular}{cccccccc}
\hline \multirow{2}{*}{ Grassland Type } & Season & \multicolumn{3}{c}{$p<\mathbf{0 . 0 1}$} & \multicolumn{3}{c}{$p<\mathbf{0 . 0 5}$} \\
\cline { 3 - 8 } & & Positive & Negative & Ratio & Positive & Negative & Ratio \\
\hline & Spring & 0.14 & 21.78 & $\mathbf{1 5 7 . 8 3}$ & 0.57 & 38.74 & $\mathbf{6 8 . 4 7}$ \\
All grasslands & Summer & 0.68 & 4.33 & $\mathbf{6 . 3 8}$ & 2.71 & 10.96 & $\mathbf{4 . 0 4}$ \\
(Area = 963,455 km²) & Autumn & 2.53 & 0.26 & 0.10 & 8.21 & 1.27 & 0.15 \\
& Annual & 0.40 & 2.82 & $\mathbf{7 . 0 7}$ & 1.74 & 9.28 & $\mathbf{5 . 3 2}$ \\
\hline & Spring & 0.14 & 23.78 & $\mathbf{1 7 3 . 2 1}$ & 0.55 & 42.33 & $\mathbf{7 6 . 9 5}$ \\
Alpine meadow & Summer & 0.69 & 3.93 & $\mathbf{5 . 6 7}$ & 2.81 & 9.86 & $\mathbf{3 . 5 0}$ \\
$\left(\right.$ Area $=479,762 \mathrm{~km}^{2}$ ) & Autumn & 2.94 & 0.24 & 0.08 & 9.11 & 1.19 & 0.13 \\
& Annual & 0.43 & 2.75 & $\mathbf{6 . 4 6}$ & 1.87 & 8.94 & $\mathbf{4 . 7 8}$ \\
\hline & Spring & 0.18 & 13.09 & $\mathbf{7 2 . 1 4}$ & 0.76 & 25.16 & $\mathbf{3 2 . 9 1}$ \\
Alpine steppe & Summer & 0.41 & 6.52 & $\mathbf{1 6 . 0 9}$ & 1.60 & 15.89 & $\mathbf{9 . 9 3}$ \\
$\left(\right.$ Area $=266,958 \mathrm{~km}^{2}$ ) & Autumn & 2.57 & 0.18 & 0.07 & 8.75 & 0.90 & 0.10 \\
& Annual & 0.32 & 3.00 & $\mathbf{9 . 3 1}$ & 1.39 & 10.34 & $\mathbf{7 . 4 3}$ \\
\hline
\end{tabular}

\subsection{Response of NPP to BGS in Different Biomes}

For the entire alpine grassland ecosystem on the TP, the relationships between BGS and NPP varied among seasons (Figure 5). Overall, spring NPP was significantly and negatively correlated with BGS ( $R=-0.73, p<0.05)$, suggesting the promoting effects of earlier BGS on spring NPP. In summer, a weaker negative correlation between BGS and NPP was observed $(R=-0.24)$. It indicated that BGS exerted weaker impacts on summer NPP than on spring NPP. However, the positive, but non-significant, correlations $(R=0.27)$ between BGS and autumn NPP indicate the down-regulation effects of earlier BGS on autumn NPP.

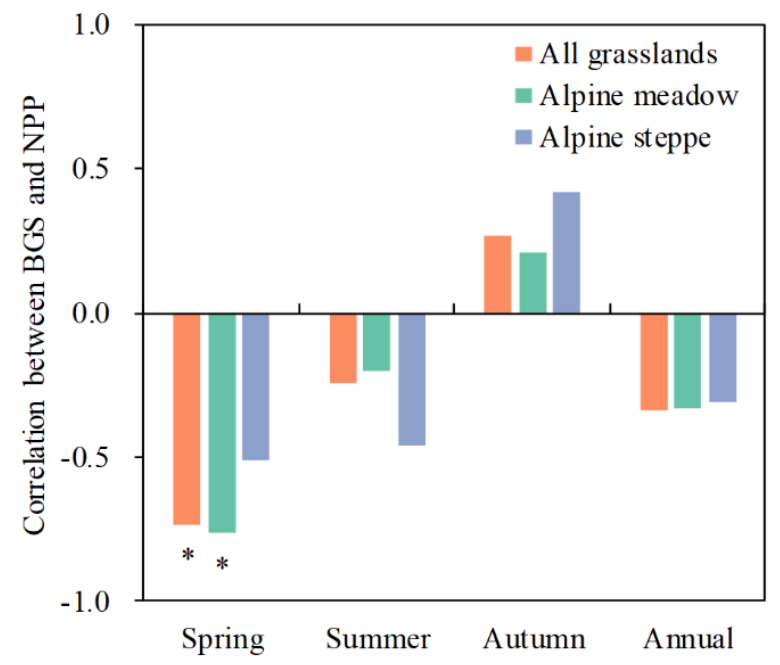

Figure 5. Correlation between beginning of growing season (BGS) and net primary productivity (NPP) in different seasons and the entire year for different biomes. ${ }^{*}$ indicates $p<0.05$.

The correlation analysis was further conducted to explore the relationships between BGS and NPP for the two major biomes (alpine meadow and steppe) separately. BGS exhibited predominant negative correlations with spring NPP and summer NPP, and a predominant positive correlation with autumn NPP in both alpine meadow and steppe (Table 2). Overall, the negative correlation magnitude between BGS and NPP weakened from spring to summer, and then the direction reversed in autumn for both alpine meadow and steppe (Figure 5). A significant negative correlation between BGS and spring NPP 
was observed in the alpine meadow $(R=-0.76, p<0.05)$, while a relatively weaker negative correlation was found in the alpine steppe $(R=-0.51)$. In summer, the negative correlation was weaker for the alpine meadow $(R=-0.20)$ than for the alpine steppe $(R=-0.46)$. The BGS also showed a weaker positive correlation with the autumn NPP for the alpine meadow $(R=0.21)$ than for the alpine steppe $(R=0.42)$.

\subsection{Correlation between BGS and NPP in Different Precipitation Classes}

We further explored the relationship between BGS and NPP in different moisture conditions. The relationship varied among different precipitation classes (Figure 6, Table 3). In spring, BGS showed predominant negative correlation with NPP for all precipitation classes at both $p<0.01$ and $p<0.05$ levels (Table 3). An overall significant negative correlation $(p<0.05)$ between BGS and spring NPP was observed for the precipitation classes of 400-600 and $>600 \mathrm{~mm}$, and the correlation magnitude strengthened from low to high precipitation class (Figure 6a). In summer, BGS exhibited a predominantly negative correlation with NPP in precipitation classes below $600 \mathrm{~mm}$ (Table 3). However, the overall significant negative correlation $(p<0.05)$ was only observed when precipitation was below $400 \mathrm{~mm}$ (Figure 6b). The relationship between BGS and summer NPP was extremely weak when precipitation was above $600 \mathrm{~mm}$. In autumn, the positive relationship between BGS and NPP dominated in all precipitation classes at both $p<0.01$ and $p<0.05$ levels (Table 3). Autumn NPP was overall positively correlated with BGS and was less responsive to BGS in more adequate precipitation classes (Figure 6c).
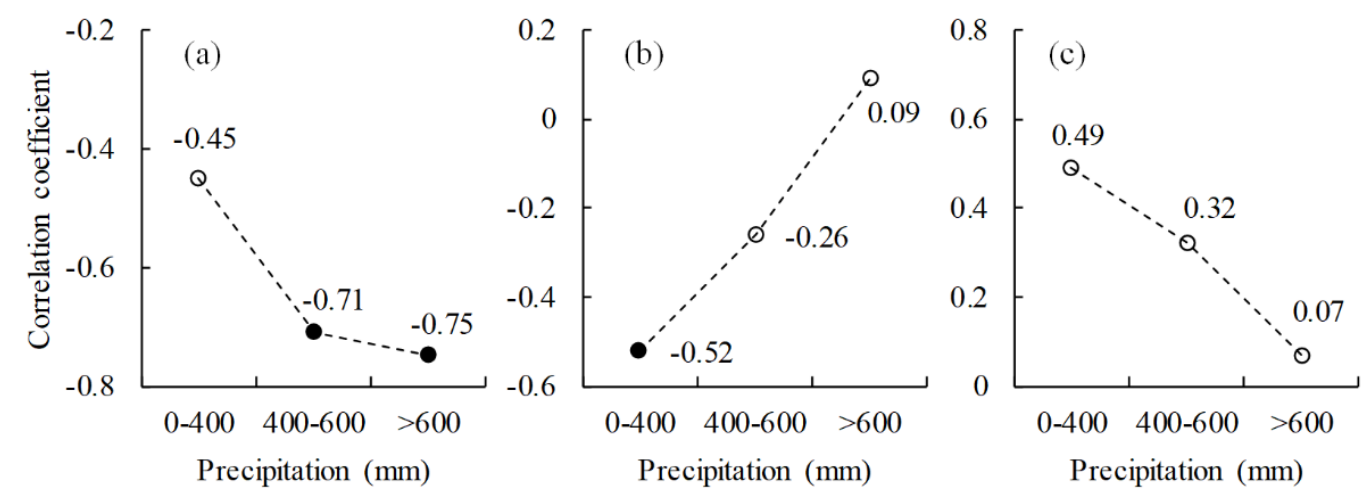

Figure 6. The correlation coefficients between beginning of growing season (BGS) and net primary productivity (NPP) in spring (a), summer (b) and autumn (c) for different mean annual precipitation classes. Circles filled with black indicate significant correlations at $p<0.05$ level.

Table 3. Areal percentage of significant correlations between beginning of growing season (BGS) and seasonal net primary productivity (NPP), and the ratio of negative correlated area to positive correlated area in different precipitation classes. Ratio values in bold and in italics indicate ratio of negative correlated area to positive correlated area $>2.0$ and $<0.5$, respectively.

\begin{tabular}{cccccccc}
\hline \multirow{2}{*}{ Season } & $\begin{array}{c}\text { Precipitation } \\
\text { Class }\end{array}$ & \multicolumn{3}{c}{$p<\mathbf{0 . 0 1}$} & \multicolumn{3}{c}{$p<\mathbf{0 . 0 5}$} \\
\cline { 2 - 8 } & Positive & Negative & Ratio & Positive & Negative & Ratio \\
\hline \multirow{3}{*}{ Spring } & $0-400 \mathrm{~mm}$ & 0.32 & 9.66 & $\mathbf{3 0 . 6 6}$ & 1.27 & 21.13 & $\mathbf{1 6 . 5 7}$ \\
& $400-600 \mathrm{~mm}$ & 0.04 & 25.68 & $\mathbf{6 2 6 . 0 0}$ & 0.18 & 44.06 & $\mathbf{2 4 6 . 9 8}$ \\
& $>600 \mathrm{~mm}$ & 0.01 & 33.52 & $\mathbf{3 4 8 3 . 5 1}$ & 0.05 & 56.19 & $\mathbf{1 0 8 6 . 0 9}$ \\
\hline \multirow{3}{*}{ Summeryyyyyyyyyyyyyy} & $0-400 \mathrm{~mm}$ & 0.42 & 8.26 & $\mathbf{1 9 . 4 9}$ & 1.64 & 18.49 & $\mathbf{1 1 . 2 6}$ \\
& $400-600 \mathrm{~mm}$ & 0.68 & 2.26 & $\mathbf{3 . 3 4}$ & 2.71 & 7.61 & $\mathbf{2 . 8 1}$ \\
\multirow{3}{*}{ Autumn } & $>600 \mathrm{~mm}$ & 1.02 & 1.41 & 1.38 & 4.13 & 4.67 & 1.13 \\
& $0-400 \mathrm{~mm}$ & 4.20 & 0.19 & 0.05 & 12.39 & 0.91 & 0.07 \\
& $400-600 \mathrm{~mm}$ & 2.02 & 0.25 & 0.12 & 7.16 & 1.24 & 0.17 \\
\hline
\end{tabular}




\section{Discussion}

\subsection{Direct and Lagged Effects of Spring Phenology on NPP}

To fully understand the interannual variability of carbon sequestration, the direct and lagged temporal effects of phenology on ecosystem productivity needs to be considered. Earlier spring phenology are expected to have direct effects on spring productivity, and lagged effects on the subsequent summer and autumn productivity. Our study revealed the different response patterns of each individual season NPP to spring phenology. According to the asymmetry analysis in correlation, BGS exhibited predominant negative correlations with spring NPP and summer NPP, and a predominant positive correlation with autumn NPP. At a regional scale, the boosting effects of BSG on spring NPP (i.e., increased NPP caused by earlier BGS), was obvious for the whole alpine grassland ecosystem $(R=-0.73, p<0.05)$. However, the boosting effects weakened dramatically from spring to summer, and the direction even reversed in autumn. It indicated that the boosting effects of earlier BGS on ecosystem NPP abated gradually in a year.

The boosting effect of earlier BGS on spring NPP was also observed in other ecosystems around the world $[23,48]$. Earlier, BGS could extend the period for photosynthetic $\mathrm{CO}_{2}$ uptake in spring by terrestrial ecosystems. Moreover, greater display of leaf area could enhance light interception and photosynthetic potential of vegetation canopy $[49,50]$. In addition, earlier spring phenology related to warming might increase the foliar nitrogen concentrations by accelerating the rate of nitrogen mineralization, thereby further enhancing photosynthetic activity [23]. We also observed that spring NPP was less correlated with BGS in areas with less precipitation. Limited water provision in arid regions can constrain plant physiological activity and undermine the stimulating effects caused by earlier BGS [51,52].

Compared with spring NPP, summer NPP was overall less correlated with BGS, which is in accord with another study in temperate China [26]. This might be resulted from the declined water availability caused by earlier BGS [28]. However, the correlation between NPP and BGS weakened more from spring to summer for alpine meadow than for the alpine steppe, as well as for areas with relatively adequate precipitations than arid regions. The BGS occurred earlier in the alpine meadow than that in the alpine steppe [16]. Then the extra water consumption in spring due to earlier BGS would be larger for the alpine meadow than for the alpine steppe. This might cause the larger decline in correlation between NPP and BGS from spring to summer for the alpine meadow.

In autumn, NPP exhibited positive correlation with BGS. In particular, the correlation magnitude strengthened from high to low precipitation class. It indicates that earlier spring phenology could aggravate the suppression of carbon assimilation in autumn in drier areas. The negative lagged effect of earlier BGS on the autumn NPP was consistent with a field-measured result on the TP [53]. Previous studies also reported a similar linkage between spring phenology and ecosystem productivity in the subsequent seasons for subalpine forests and temperate grasslands [25,54]. Differently to those studies, the suppression effect on productivity occurred in autumn, rather than summer in our study. The negative lagged effect of spring phenology on the autumn productivity might be caused by several reasons. Earlier spring growth could deplete soil water resources by increasing transpiration $[25,55,56]$, consequently suppressing the physiological activities of vegetation. In addition, a decline in water availability can decrease plant nutrient uptake by reducing nutrient supply through mineralization, nutrient diffusion and mass flow in the soil [57-59], which also results in declined NPP.

Previous studies reported the boosting effects of earlier spring phenology on annual carbon assimilation [23,60]. However, for the unique alpine grasslands of the TP, the increased NPP in spring was offset by decreased NPP in autumn on the whole, resulting in no obvious relationship between BGS and annual NPP. It indicated that earlier BSG might not result in increased annual NPP, which corroborates the finding of previous study [20]. Other studies also confirmed that BGS was not the dominant contributor to annual carbon assimilation in the TP [18,19]. However, the role of spring phenology in regulating seasonal carbon dynamics through direct and lagged ways should be paid 
mounting attention. For example, warming-induced earlier BGS might lead to declined grassland productivity in autumn, which would limit the grassland carrying capacity. Then the livestock stocking rates need to decrease to match the grassland productivity and to maintain the human-nature balance. Therefore, improved knowledge on the relationship between BGS and ecosystem NPP is beneficial for implementing a plethora of sustainable development policies, such as grazing management and vegetation restorations.

\subsection{Uncertainties}

In this study, we were aimed to explore the direct and lagged effects of spring phenology on ecosystem NPP by seasons and assess the related water resources availability caused by earlier start of growing season. Autumn phenology can affect autumn and annual NPP to a certain extent. Due to its low accuracies as captured by remote sensing [33,61,62], and its minor effects on annual water budget, autumn phenology was not considered in this study. In the future, effects of autumn phenology entail to be considered in combination with spring phenology. Field monitoring is also critical. The field phenology and NPP observation sites in this study are mostly located in the central and eastern parts of the TP. Additional field sites need to be set up in the remote western plateau to provide in-situ validation on remote sensing products. In addition, anthropogenic activities, including grazing, can affect phenology and ecosystem productivity [20], which also need to be further investigated in the future. Besides, snowmelt can influence the effective precipitation for vegetation growth, which should be further considered to obtain a comprehensive understanding of the relationship between water availability and the response of vegetation productivity to phenology.

\section{Conclusions}

In this study, we revealed the direct and lagged effects of BGS on NPP for the alpine grassland on the TP, and how they were regulated by water resource limitation. The results showed direct positive effects of earlier BGS on spring NPP, and the positive effects were more pronounced in moisturized areas. Though earlier BGS exerted positive lagged effects on summer NPP, the boosting effects of earlier BGS on summer NPP was weaker than on spring NPP. Moreover, our study revealed the negative lagged effects of earlier BGS on autumn NPP, especially in dry parts of the TP. The counterbalance among each season resulted in neutral effects of earlier BGS on annual NPP. The lagged effects of spring phenology on the subsequent seasonal productivity may help provide suggestions on optimizing the timing of grazing in alpine grasslands under changing growing season conditions.

Author Contributions: Conceptualization, Z.Z. and W.Z.; methodology, Z.Z.; software, W.Z.; validation, Z.Z.; formal analysis, Z.Z.; resources, W.Z. and Y.Z.; data curation, W.Z.; writing-original draft preparation, Z.Z.; writing-review and editing, Y.Z.; visualization, Z.Z.; supervision, Y.Z.; project administration, Y.Z.; funding acquisition, Y.Z. All authors have read and agreed to the published version of the manuscript.

Funding: This research was funded by the strategic priority research program of the Chinese Academy of Sciences (XDA19070303), the National Natural Science Foundation of China (41901131, 41725003 and 41771047) and CAS Interdisciplinary Innovation Team (JCTD-2018-06).

Acknowledgments: We thank the National Aeronautics and Space Administration (NASA) and the United States Geological Survey (USGS) for providing MODIS satellite data. We also thank the China Meteorological Administration for providing field data and meteorological data.

Conflicts of Interest: The authors declare no conflict of interest.

\section{References}

1. Niu, S.; Fu, Z.; Luo, Y.; Stoy, P.C.; Keenan, T.F.; Poulter, B.; Zhang, L.; Piao, S.; Zhou, X.; Zheng, H.; et al. Interannual variability of ecosystem carbon exchange: From observation to prediction. Glob. Chang. Biol. 2017, 26, 1225-1237. [CrossRef] 
2. Shao, J.; Zhou, X.; Luo, Y.; Li, B.; Aurela, M.; Billesbach, D.; Blanken, P.D.; Bracho, R.; Chen, J.; Fischer, M.; et al. Biotic and climatic controls on interannual variability in carbon fluxes across terrestrial ecosystems. Agric. For. Meteorol. 2015, 205, 11-22. [CrossRef]

3. Polley, H.W.; Frank, A.B.; Sanabria, J.; Phillips, R.L. Interannual variability in carbon dioxide fluxes and flux-climate relationships on grazed and ungrazed northern mixed-grass prairie. Glob. Chang. Biol. 2008, 14, 1620-1632. [CrossRef]

4. Wu, C.; Chen, J.M.; Black, T.A.; Price, D.T.; Kurz, W.A.; Desai, A.R.; Gonsamo, A.; Jassal, R.S.; Gough, C.M.; Bohrer, G.; et al. Interannual variability of net ecosystem productivity in forests is explained by carbon flux phenology in autumn. Glob. Chang. Biol. 2013, 22, 994-1006. [CrossRef]

5. Richardson, A.D.; Black, T.A.; Ciais, P.; Delbart, N.; Friedl, M.A.; Gobron, N.; Hollinger, D.Y.; Kutsch, W.L.; Longdoz, B.; Luyssaert, S.; et al. Influence of spring and autumn phenological transitions on forest ecosystem productivity. Philos. Trans. R. Soc. B-Biol. Sci. 2010, 365, 3227-3246. [CrossRef]

6. Cleland, E.E.; Chuine, I.; Menzel, A.; Mooney, H.A.; Schwartz, M.D. Shifting plant phenology in response to global change. Trends Ecol. Evol. 2007, 22, 357-365. [CrossRef]

7. Parmesan, C.; Yohe, G. A globally coherent fingerprint of climate change impacts across natural systems. Nature 2003, 421, 37-42. [CrossRef]

8. Schwartz, M.D.; Ahas, R.; Aasa, A. Onset of spring starting earlier across the Northern Hemisphere. Glob. Chang. Biol. 2006, 12, 343-351. [CrossRef]

9. Root, T.L.; Price, J.T.; Hall, K.R.; Schneider, S.H.; Rosenzweig, C.; Pounds, J.A. Fingerprints of global warming on wild animals and plants. Nature 2003, 421, 57-60. [CrossRef]

10. Richardson, A.D.; Keenan, T.F.; Migliavacca, M.; Ryu, Y.; Sonnentag, O.; Toomey, M. Climate change, phenology, and phenological control of vegetation feedbacks to the climate system. Agric. For. Meteorol. 2013, 169, 156-173. [CrossRef]

11. White, M.A.; de Beurs, K.M.; Didan, K.; Inouye, D.W.; Richardson, A.D.; Jensen, O.P.; O’Keefe, J.; Zhang, G.; Nemani, R.R.; van Leeuwen, W.J.D.; et al. Intercomparison, interpretation, and assessment of spring phenology in North America estimated from remote sensing for 1982-2006. Glob. Chang. Biol. 2009, 15, 2335-2359. [CrossRef]

12. Shen, M.; Piao, S.; Dorji, T.; Liu, Q.; Cong, N.; Chen, X.; An, S.; Wang, S.; Wang, T.; Zhang, G. Plant phenological responses to climate change on the Tibetan Plateau: Research status and challenges. Natl. Sci. Rev. 2015, 2, 454-467. [CrossRef]

13. Zhang, Y.; Zhu, Y.; Li, J.; Chen, Y. Current status and future directions of the Tibetan Plateau ecosystem research. Sci. Bull. 2019, 64, 428-430. [CrossRef]

14. Piao, S.; Tan, K.; Nan, H.; Ciais, P.; Fang, J.; Wang, T.; Vuichard, N.; Zhu, B. Impacts of climate and $\mathrm{CO}_{2}$ changes on the vegetation growth and carbon balance of Qinghai-Tibetan grasslands over the past five decades. Glob. Planet. Chang. 2012, 98-99, 73-80. [CrossRef]

15. Duan, A.; Xiao, Z. Does the climate warming hiatus exist over the Tibetan Plateau? Sci. Rep. 2015, 5, 13711. [CrossRef] [PubMed]

16. Zhang, G.; Zhang, Y.; Dong, J.; Xiao, X. Green-up dates in the Tibetan Plateau have continuously advanced from 1982 to 2011. Proc. Natl. Acad. Sci. USA 2013, 110, 4309-4314. [CrossRef]

17. Zheng, Z.; Zhu, W.; Chen, G.; Jiang, N.; Fan, D.; Zhang, D. Continuous but diverse advancement of spring-summer phenology in response to climate warming across the Qinghai-Tibetan Plateau. Agric. For. Meteorol. 2016, 223, 194-202. [CrossRef]

18. Chen, S.; Huang, Y.; Gao, S.; Wang, G. Impact of physiological and phenological change on carbon uptake on the Tibetan Plateau revealed through GPP estimation based on spaceborne solar-induced fluorescence. Sci. Total. Environ. 2019, 663, 45-59. [CrossRef]

19. Jin, J.; Ma, X.; Chen, H.; Wang, H.; Kang, X.; Wang, X.; Wang, Y.; Yong, B.; Guo, F. Grassland production in response to changes in biological metrics over the Tibetan Plateau. Sci. Total. Environ. 2019, 666, 641-651. [CrossRef]

20. Wang, S.; Zhang, B.; Yang, Q.; Chen, G.; Yang, B.; Lu, L.; Shen, M.; Peng, Y. Responses of net primary productivity to phenological dynamics in the Tibetan Plateau, China. Agric. For. Meteorol. 2017, 232, $235-246$. [CrossRef] 
21. Tao, J.; Dong, J.; Zhang, Y.; Yu, X.; Zhang, G.; Cong, N.; Zhu, J.; Zhang, X. Elevation-dependent effects of growing season length on carbon sequestration in Xizang Plateau grassland. Ecol. Indic. 2020, 110, 105880. [CrossRef]

22. Buermann, W.; Forkel, M.; O Sullivan, M.; Sitch, S.; Friedlingstein, P.; Haverd, V.; Jain, A.K.; Kato, E.; Kautz, M.; Lienert, S. Widespread seasonal compensation effects of spring warming on northern plant productivity. Nature 2018, 562, 110-114. [CrossRef] [PubMed]

23. Richardson, A.D.; Hollinger, D.Y.; Dail, D.B.; Lee, J.T.; Munger, J.W.; O’Keefe, J. Influence of spring phenology on seasonal and annual carbon balance in two contrasting New England forests. Tree Physiol. 2009, 29, 321-331. [CrossRef] [PubMed]

24. Dragoni, D.; Schmid, H.P.; Wayson, C.A.; Potter, H.; Grimmond, C.S.B.; Randolph, J.C. Evidence of increased net ecosystem productivity associated with a longer vegetated season in a deciduous forest in south-central Indiana, USA. Glob. Chang. Biol. 2011, 17, 886-897. [CrossRef]

25. Yu, Z.; Lu, C.; Cao, P.; Tian, H.; Hessl, A.; Pederson, N. Earlier leaf-flushing suppressed ecosystem productivity by draining soil water in the Mongolian Plateau. Agric. For. Meteorol. 2018, 250, 1-8. [CrossRef]

26. Zhou, X.; Geng, X.; Yin, G.; Hänninen, H.; Hao, F.; Zhang, X.; Fu, Y.H. Legacy effect of spring phenology on vegetation growth in temperate China. Agric. For. Meteorol. 2020, 281, 107845. [CrossRef]

27. Kim, J.H.; Hwang, T.; Yang, Y.; Schaaf, C.L.; Boose, E.; Munger, J.W. Warming-induced earlier greenup leads to reduced stream discharge in a temperate mixed forest catchment. J. Geophys. Res.-Biogeosci. 2018, 123, 1960-1975. [CrossRef]

28. Lian, X.; Piao, S.; Li, L.Z.; Li, Y.; Huntingford, C.; Ciais, P.; Cescatti, A.; Janssens, I.A.; Peñuelas, J.; Buermann, W. Summer soil drying exacerbated by earlier spring greening of northern vegetation. Sci. Adv. 2020, 6, eaax0255. [CrossRef]

29. Zheng, Z.; Zhu, W.; Zhang, Y. Seasonally and spatially varied controls of climatic factors on net primary productivity in alpine grasslands on the Tibetan Plateau. Glob. Ecol. Conserv. 2020, 21, e00814. [CrossRef]

30. Zhang, X.; Tarpley, D.; Sullivan, J.T. Diverse responses of vegetation phenology to a warming climate. Geophys. Res. Lett. 2007, 34, L1940519. [CrossRef]

31. Chen, J.; Jonsson, P.; Tamura, M.; Gu, Z.H.; Matsushita, B.; Eklundh, L. A simple method for reconstructing a high-quality NDVI time-series data set based on the Savitzky-Golay filter. Remote. Sens. Environ. 2004, 91, 332-344. [CrossRef]

32. Holben, B.N. Characteristics of maximum-value composite images from temporal AVHRR data. Int. J. Remote. Sens. 1986, 7, 1417-1434. [CrossRef]

33. Zheng, Z.; Zhu, W. Uncertainty of remote sensing data in monitoring vegetation phenology: A comparison of MODIS C5 and C6 vegetation index products on the Tibetan Plateau. Remote. Sens. 2017, 9, 1288. [CrossRef]

34. China Meteorological Administration. Observation Criterion of Agricultural Meteorology; China Meteorological Press: Beijing, China, 1993.

35. Ren, S.; Chen, X.; Lang, W.; Schwartz, M.D. Climatic controls of the spatial patterns of vegetation phenology in midlatitude grasslands of the Northern Hemisphere. J. Geophys. Res.-Biogeosci. 2018, 123, 2323-2336. [CrossRef]

36. Meyer, S.T.; Koch, C.; Weisser, W.W. Towards a standardized rapid ecosystem function assessment (REFA). Trends Ecol. Evol. 2015, 30, 390-397. [CrossRef] [PubMed]

37. Fang, J.; Guo, Z.; Piao, S.; Chen, A. Terrestrial vegetation carbon sinks in China, 1981-2000. Sci. China Ser. D Earth Sci. 2007, 50, 1341-1350. [CrossRef]

38. Prescott, J.A. Evaporation from a water surface in relation to solar radiation. Trans. R. Soc. S. Aust. 1940, 64, 114-118.

39. Angstrom, A. Solar and terrestrial radiation. Q. J. R. Meteorol. Soc. 1924, 50, 121-126. [CrossRef]

40. Hutchinson, M.F. Anusplin Version 4.3; Center for Resource and Environmental Studies, The Australian National University: Canberra, Australia, 2004.

41. Editorial Board of Vegetation Map of China, Chinese Academy of Sciences. Vegetation Map of the People's Republic of China (1:1000000) (Digital Version); Geology Press: Beijing, China, 2007.

42. Zhang, X.Y.; Friedl, M.A.; Schaaf, C.B.; Strahler, A.H.; Hodges, J.; Gao, F.; Reed, B.C.; Huete, A. Monitoring vegetation phenology using MODIS. Remote. Sens. Environ. 2003, 84, 471-475. [CrossRef]

43. Field, C.B.; Randerson, J.T.; Malmstrom, C.M. Global net primary production: Combining ecology and remote sensing. Remote. Sens. Environ. 1995, 51, 74-88. [CrossRef] 
44. Potter, C.S.; Randerson, J.T.; Field, C.B.; Matson, P.A.; Vitousek, P.M.; Mooney, H.A.; Klooster, S.A. Terrestrial ecosystem production-a process model-based on global satellite and surface data. Glob. Biogeochem. Cycles 1993, 7, 811-841. [CrossRef]

45. Zhu, W.Q.; Pan, Y.Z.; He, H.; Yu, D.Y.; Hu, H.B. Simulation of maximum light use efficiency for some typical vegetation types in China. Chin. Sci. Bull. 2006, 51, 457-463. [CrossRef]

46. Li, Y.; Huang, J.; Ji, M.; Ran, J. Dryland expansion in northern China from 1948 to 2008. Adv. Atmos. Sci. 2015, 32, 870-876. [CrossRef]

47. Tomaszewska, M.A.; Nguyen, L.H.; Henebry, G.M. Land surface phenology in the highland pastures of montane Central Asia: Interactions with snow cover seasonality and terrain characteristics. Remote. Sens. Environ. 2020, 240, 111675. [CrossRef]

48. Keenan, T.F.; Gray, J.; Friedl, M.A.; Toomey, M.; Bohrer, G.; Hollinger, D.Y.; Munger, J.W.; O'Keefe, J.; Schmid, H.P.; Suewing, I.; et al. Net carbon uptake has increased through warming-induced changes in temperate forest phenology. Nat. Clim. Chang. 2014, 4, 598-604. [CrossRef]

49. Jolly, W.M.; Nemani, R.; Running, S.W. Enhancement of understory productivity by asynchronous phenology with overstory competitors in a temperate deciduous forest. Tree Physiol. 2004, 24, 1069-1071. [CrossRef] [PubMed]

50. Luyssaert, S.; Janssens, I.A.; Sulkava, M.; Papale, D.; Dolman, A.J.; Reichstein, M.; Hollmen, J.; Martin, J.G.; Suni, T.; Vesala, T.; et al. Photosynthesis drives anomalies in net carbon-exchange of pine forests at different latitudes. Glob. Chang. Biol. 2007, 13, 2110-2127. [CrossRef]

51. Huxman, T.E.; Snyder, K.A.; Tissue, D.; Leffler, A.J.; Ogle, K.; Pockman, W.T.; Sandquist, D.R.; Potts, D.L.; Schwinning, S. Precipitation pulses and carbon fluxes in semiarid and arid ecosystems. Oecologia 2004, 141, 254-268. [CrossRef] [PubMed]

52. Coe, K.K.; Belnap, J.; Sparks, J.P. Precipitation-driven carbon balance controls survivorship of desert biocrust mosses. Ecology 2012, 93, 1626-1636. [CrossRef] [PubMed]

53. Wang, H.; Liu, H.; Cao, G.; Ma, Z.; Li, Y.; Zhang, F.; Zhao, X.; Zhao, X.; Jiang, L.; Sanders, N.J. Alpine grassland plants grow earlier and faster but biomass remains unchanged over 35 years of climate change. Ecol. Lett. 2020, 23, 701-710. [CrossRef]

54. Hu, J.; Moore, D.J.P.; Burns, S.P.; Monson, R.K. Longer growing seasons lead to less carbon sequestration by a subalpine forest. Glob. Chang. Biol. 2010, 16, 771-783. [CrossRef]

55. Beck, P.S.A.; Goetz, S.J. Satellite observations of high northern latitude vegetation productivity changes between 1982 and 2008: Ecological variability and regional differences. Environ. Res. Lett. 2011, 6, 45501. [CrossRef]

56. Buermann, W.; Bikash, P.R.; Jung, M.; Burn, D.H.; Reichstein, M. Earlier springs decrease peak summer productivity in North American boreal forests. Environ. Res. Lett. 2013, 8, 24027. [CrossRef]

57. Sanaullah, M.; Rumpel, C.; Charrier, X.; Chabbi, A. How does drought stress influence the decomposition of plant litter with contrasting quality in a grassland ecosystem? Plant Soil 2012, 352, 277-288. [CrossRef]

58. He, M.; Dijkstra, F.A. Drought effect on plant nitrogen and phosphorus: A meta-analysis. New Phytol. 2014, 204, 924-931. [CrossRef] [PubMed]

59. Cramer, M.D.; Hawkins, H.; Verboom, G.A. The importance of nutritional regulation of plant water flux. Oecologia 2009, 161, 15-24. [CrossRef]

60. Wu, C.; Gonsamo, A.; Chen, J.M.; Kurz, W.A.; Price, D.T.; Lafleur, P.M.; Jassal, R.S.; Dragoni, D.; Bohrer, G.; Gough, C.M.; et al. Interannual and spatial impacts of phenological transitions, growing season length, and spring and autumn temperatures on carbon sequestration: A North America flux data synthesis. Glob. Planet. Chang. 2012, 92-93, 179-190. [CrossRef]

61. Gallinat, A.S.; Primack, R.B.; Wagner, D.L. Autumn, the neglected season in climate change research. Trends Ecol. Evol. 2015, 30, 169-176. [CrossRef]

62. Wu, C.; Peng, D.; Soudani, K.; Siebicke, L.; Gough, C.M.; Arain, M.A.; Bohrer, G.; Lafleur, P.M.; Peichl, M.; Gonsamo, A.; et al. Land surface phenology derived from normalized difference vegetation index (NDVI) at global FLUXNET sites. Agric. For. Meteorol. 2017, 233, 171-182. [CrossRef]

(C) 2020 by the authors. Licensee MDPI, Basel, Switzerland. This article is an open access article distributed under the terms and conditions of the Creative Commons Attribution (CC BY) license (http://creativecommons.org/licenses/by/4.0/). 